\title{
Industrial Waste Management and Environment: A Study in Kamrangirchar (Raised Land), Dhaka
}

\author{
Shahanaz Akter \\ Department of Sociology, Noakhali Science and Technology University, Noakhali, Bangladesh
}

Md. Muniruzzaman (Corresponding author)

Department of Sociology, Noakhali Science and Technology University, Noakhali, Bangladesh

Received: October 15, 2020 Accepted: November 21, 2020 Published: December 21, 2020

doi:10.5296/emsd.v10i1.17825 URL: https://doi.org/10.5296/emsd.v10i1.17825

\begin{abstract}
Kamrangirchar is a raised land and industrial area situated on the bank of the Buriganga River in Dhaka city. The industries of this area are producing a huge amount of solid and liquid wastes all of which are disposed into the Buriganga river and other nearby places. This study attempts to explore the scenario of industrial waste management in Kamrangirchar (raised land) and its effect on the surrounding environment. The methodology of this study includes in-depth interviews and tries to explore the ways of managing waste properly. This study tries to explore more effective ways of managing industrial waste for a sound and safe environment. Environmental pollution has been a major global problem nowadays. Nature is being destroyed because of the excessive exploitation of the environment. Some elements of the environment and ecology like forests, natural sources of water, land, and air are gradually being polluted in Bangladesh, although these are essential for survival. Lack of awareness of the industrial units, poor implementation of the government policy of industrial waste management, inappropriate initiatives to dispose of the waste properly, and ineffective laws are responsible for the improper management of industrial waste in Kamrangirchar which is affecting the environment directly and indirectly.
\end{abstract}

Keywords: Industrial waste, Waste management, Environment, Raised land

\section{Introduction}

Bangladesh is a country that faces demographic challenges dragging her into a state of rising urbanization, exclusive industrialization, and increasing consumption (MOEF, 2013). The result is the rapid growth of industries generating huge waste and disruption of the environment. Because of fast urbanization waste management has become a serious problem 
today. Improper collection, separation, and disposal of industrial waste have been a growing concern in Bangladesh (Ministry of Environment and Forests, 2010). The environment is the most important part of life in this world. Nowadays, we can see how our environment is being disrupted indiscriminately. The rapid and huge generation of industrial waste is creating a serious burden on our natural environmental resources which is a big challenge for sustainable development. Due to various factors, the number of industries is increasing rapidly in both sides of the Buriganga River, especially in Kamrangirchar area. Most of the industries are not implementing the Government Waste Management Policy properly. These industries are producing huge waste those are disposed of either in the open air or in the river (Tania, 2014).

It has been a matter of concern that these vast amounts of waste are not collected and managed properly. It is a must to make sure that the government policy of waste management is implemented by the industrial units. Poor industrial waste management causes severe environmental risks and pollution. Water, air, soil, etc. and overall environment are being polluted and agricultural production is being affected by this.

The government of Bangladesh adopted its first-ever national 3R strategy for waste management in 2010.This strategy articulates the framework of the government's 3R policy and aims at the prevention of excessive use of resources, minimization of waste, recurrence of use, reprocessing of waste for repeated use of recycling, recovery, etc. (MOEF, 2013)). Most of the industries don't follow or implement the government policy of waste management and our environment is paying the brutal costs.

The rising quality of life and high rates of resource consumption patterns have had an enormous either intended or unintended negative impacts on the environment. Waste generation is crossing the handling capacities of government and agencies. The uncollected wastes are dumped in open spaces and on the roadsides results jam in the drainage system creating serious hazards, environmental pollution, and health risks in the city. The waste management practice in Dhaka city is not satisfactory and needs adequate policy and awareness. Consciousness and responsiveness to various aspects of waste management can help decline waste generation and improve waste management system (Yasmin \& Rahman, 2017). Many investigations and researches have been conducted by government and non-government organizations that are not sufficient to throw light on the problem. Although industrial wastes are not managed in a proper way, no considerable research work has been conducted on the lack of implementation of the government policy of waste management and environmental risks.

Under these circumstances, a sociological study will be very effective to explore the waste management system and its impact on the environment. As a result, we have been insisted to conduct this study so that people can learn about the waste management system of the industries of Bangladesh, the causes of not implementing government policies, and environmental risks. This study will help the government, environment policymakers, legislators and agencies to ensure necessary initiatives. The study is intended to accomplish the following objectives: 
- To explore the relationship between industrial waste management and environment.

- To identify the existing waste management system in Kamrangirchar area.

- To explore more effective ways of managing industrial waste for a sound and safe environment.

\section{Literature Review}

Bangladesh has already received a declaration that it is going to acquire the status of Developing Country by fulfilling the UN conditions by 2024. Bangladesh is a small country with a large population. The speed of urbanization and industrialization is increasing day by day in this country. After becoming a developing country, industrialization will also spread rapidly in Bangladesh; this will be very alarming for Bangladesh if the industrial waste management scenario does not change.

\subsection{Waste Management Scenario of Dhaka City}

Waste is something that can be produced by household activities, hospitals, industrialization, urbanization, etc. According to C L Hand, Waste, by definition, is something that the producer no longer wants and throw-outs. In many developing countries' industrial economies, the traditional practice to waste has been to dispose of it as cheaply as possible, without much concern about the environment once the waste leaves the producer's premises (Hand, 2009).

Dhaka City is now facing the problem of huge bulks of wastes. This problem has an in-depth effect on the environment as these wastes are not managed properly. Industrialists, employees, and general people have to be aware of the impact of mismanagement of industrial wastes on the environment and proper disposal of these wastes must be ensured. The community and all the sectors have to engage in this work concerning behavior changes and awareness-raising. A healthy planned waste management process will not only help to keep the environment sound and safe but it will also be cost-effective. Dhaka City Corporations are mainly maintaining this responsibility (Tania, 2014).

The waste generation rate of Bangladesh is increasing and it is projected to reach 47, 064 tons per day by 2025. The waste generation rate is projected to increase to 0.6 in 2025. The total waste gathering rate in major cities of Bangladesh such as Dhaka is only $37 \%$. When waste is not properly collected, it will be randomly disposed of here and there and this will pose serious environmental and health hazards to the people. Four types of waste streams i.e. Domestic (49\%), commercial, (21\%), industrial, (24\%), and hospital, (6\%) constitute the total solid wastes of Dhaka city. Activities of Dhaka city-corporation include- sweeping roads \& drains daily, accumulating wastes from the roadside and nearest dustbin/container, dumping to the dumping depots by trucks, dredging by bulldozers, tire dozers, pay loaders \& excavators (Islam, 2016).

Only about $42 \%$ of the generated waste is collected and dumped at landfill sites, and the rest is left uncollected. As much as 400 tons of wastes are dumped on the roadside and in open spaces indiscriminately (Amin, 2017). 


\subsection{Proper Waste Management System}

According to Islam (Islam, 2016), there are many sources of waste production, but most potential sources are residential and commercial sources. Different commercial and residential sources are-domestic waste, hospital and clinic waste, and tanning waste.

According to Hand, worthy waste management includes much more than confirming that wastes are safely and legally disposed of. The aim should be to attain the best possible environmental option for each waste volume. A typical strategy for the management of industrial waste might cover the following features (Hand, 2009):

a) audit of wastes produced and recent waste management measures

b) risk assessment to ensure that loading and controlling procedures do not produce health hazard and environmental risk

c) inspecting of chances for waste reduction, reuse, recycling and recovery

d) valuation of waste management options

e) searching potential waste management contractors.

Any waste management strategy should categorize the wastes produced based on their characteristics for its proper implementation. Before moving forward to any management and control of waste, its elements must be known to enact the strategy. At first, the industries should be identified which are disposing hazardous waste, and then the nature of the waste and their possible impact on nature should be determined (Vani, Bhaumik, Nandan, \& Siddiqui, 2017). A proper waste management system requires sustainable and environment-friendly transportation facilities to dispose of the produced wastes in legally decided area.

\subsection{Procedure of Waste Management in City Corporation Act 2009}

According to Amin, The City Corporation Act, 2009 states the following measures regarding waste management in urban areas of Bangladesh (Amin, 2017):

a. Corporation will ensure collection of waste and removal of it from all the roads, public toilets, drains and buildings.

b. Corporation will be responsible for collecting waste from all the areas and buildings under its jurisdiction.

c. Corporation will manage dustbins or other bins in various areas of the city.

d. The employees of the Corporation and the waste collected by them or the city corporation and the waste dumped into the dustbins will be considered as their property.

\subsection{Waste Management Strategies and Environmental Policies and Acts}

Rapid and unplanned industrialization and urbanization have made the waste management a serious challenge for the municipalities in developing countries like Bangladesh with increasing amount of waste. Municipal solid waste management of Dhaka city seems to be a matter of gathering waste and then getting rid of it by throwing anywhere overlooking the benefits of recycling to reduce and recovery and safe disposal/treatment of waste ( Matter, Dietschi, \& Zurbrügg, 2013). The legal framework for environmental protection in general 
and waste management/3R strategy, in particular, got a big boost from the 2011 amendment of the constitution. This article states: Protection and improvement of environment and biodiversity - The state shall endeavor to protect and improve the environment and to preserve and safeguard the natural resources, biodiversity, wetlands, forests and wild life for the present and future citizens (Article 18A, Constitution of Bangladesh, Bangladesh Government, 2011, p. 27. Regulatory framework for environmental protection and management started from 1992. Then the Environmental Conservation Act arose in1995 that incorporated a definition of waste. The Environmental Court Act of 2000 was a pioneering act for taking action on violations of environmental laws and regulations but waste-related offenses were not specified. It was more directed at polluters or pollution. A major change, however, took place in 2013 when the National Environmental Policy recognized the 3R strategy, adopted by the government in 2010, as an appropriate strategy for waste management (Amin, 2017).

The Australian government has a long history of association on waste management policy and measures. The first Australian widespread national approach to waste management was taken under the 1992 National Strategy for Ecologically Sustainable Development by the Council of Australian Governments which was dedicated to improve the use of resources, reduce the impact of waste disposal on the environment and improve the management system of hazardous wastes; avoid their production and address hygienic final disposal (Australian Government, Department of Agriculture, Water and the Environment, 2013).

\subsection{The 3Rs Policy for Waste Management}

Waste management procedures are implemented through national 3R policy. It was developed in collaboration with the United Nations Centre for Regional development and Ministry of Environment of Government of Japan. Waste Concern technically helped to prepare it. The goal of national $3 \mathrm{R}$ policy for waste management is to reach elimination of waste disposal on open landfills and rivers by 2015 and promote recycling of waste. The Recent 5R (Re-think, Reduce, Recycle, Recovery, and Re-use) policy is more fruitful from 3R. So, Bangladesh should shift from 3R to 5R soon (Nasrin \& Farjana, 2016).

The 3rs are defined as the principle of Reduce, Re-using and recycle of resources and products. The utmost motto of the 3rs strategy is to minimize the amount of waste as far as possible ensuring the proper production of necessary products. The 3rs strategy is based on a hierarchy of waste which is shown in the figure below: 


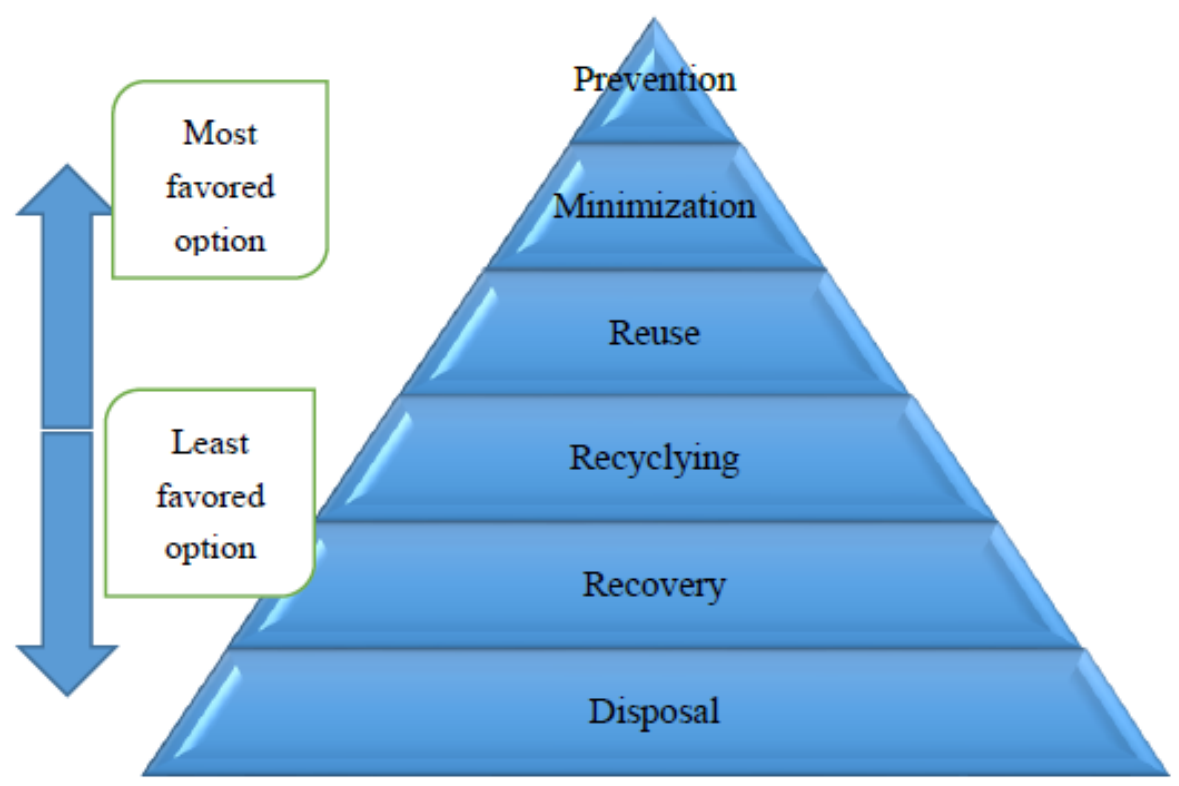

Figure 1. 3Rs' Hierarchy of Waste Management

Source: (Ministry of Environment and Forests, 2010)

\subsection{Waste Management Scenario in Different Countries}

In Nepal, all kinds of waste generation have been increased rapidly accompanied by the lack of consciousness, proper waste management amenities, monitoring, and harmonization among the involved party for the management of waste. Only some large-scale industries among over 3,500 registered industrial establishments release wastes, sewages, and emissions maintaining waste management standards. Mostly wastes without value are disposed of without any environmental consideration. Liquid wastes are usually discharged straight to drains that ultimately flow into surface waters, rivers, or lakes. Environmentally sound disposal facilities are very limited in Nepal. Bhutan is still in the initial phase concerning hazardous waste management lacking established institutional and legal outlines to evaluate the improper management of hazardous wastes yet. A proper system of hazardous waste management desires to be given importance in order to assure a safe environment and public health. India has significant challenges in hazardous waste management requiring reconsiderations to the existing system. (Green, 2010)

\subsection{Impact of Poor Waste Management on Environment}

The environmental risks associated with poor waste management are well known. Fly moved wastes can cause fatal diseases and injure children and animals. Careless disposal of liquid wastes of industries, such as solvents, can leak into the groundwater and contaminate drinking water supplies. Ill managed landfills will create significant neighborhood trouble, and where landfill gas and leachate are not properly treated there will be a serious threat to the safety of local residents. Old, closed dumps and landfills are likely to be contaminated land which may be difficult or dangerous. Waste producers should carry their share of 
responsibility to ensure that such polluting incidents do not occur. Good waste management protects the environment and improves profitability (Hand, 2009). Improper waste management practices can therefore generate hazardous and risky conditions of the environment resulting in a perilous situation for society. Indiscriminate dumping of hazardous industrial waste anywhere in the environment can cause both instant and long-lasting effects on human life and the environment. Long time exposure to hazardous waste by the human can make acute health problems such as cancer, genetic defects, central nervous system disorder, and congenital anomalies, etc. One of the cases of contamination in the past due to unsafe disposal of industrial wastes received attention is the love canal incident in New York. Love canal was used as the dumping site for hazardous chemical wastes for a long period of about25 to 30 years. Subsequent disposal of wastes into the site resulted in very serious health deficiencies in the neighborhood residents. Similar occurrences are documented in other locations of the USA, Europe, Japan, and Asia, etc. (Misra \& Pandey, 2006). Dumping wastes on open-air create an unhygienic environment and pose an enormous threat to the people. It also promotes the spread of diseases, pollutes water bodies, produces Carbon dioxide, and Methane which is extremely harmful to the environment (Islam, 2016). Many developing countries in Asia, such as Bangladesh, Bhutan, Nepal, and India are facing an increasing economic development including industrial, agricultural, health services and others economic services which is triggering a large volume of hazardous wastes unmanaged resulting in serious environmental problems threatening public health and economic sustainability (Green, 2010).

Many rivers are severely being polluted and the hazardous wastes from industrial activities are increasing released into the environment without proper treatment. The river Buriganga is one of the most important examples of pollution of water bodies by hazardous industrial waste from industries situated on the bank of Buriganga in Dhaka, Bangladesh. Challenges and solutions for solid waste management in the context of different countries and urban hubs are not new and a lot of research studies are available regarding the impact of poor waste management on the environment and public health. This research has escorted inclusive literature search and analysis and found that Dhaka city has a similar context. The literature review also shows that proper management of industrial waste and its impact on the environment and public health are of great challenges in different countries. Several studies were conducted into Dhaka city but Kamrangirchar was not included though it is situated on a very important River named Buriganga on the bank of which Dhaka city is situated. Another important reason for choosing this area is its location surrounded by water bodies and residential areas. In the context of the environment, the Kamrangirchar area is very important as the number of industries is increasing due to easy transportation system of both road and waterways and cheap labor power.

\section{Methodology}

The qualitative research method was used to conduct this study. The nature and subject matter of this study has influenced the researchers to adopt the qualitative methodology. The topic of the study needs deep, explorative, and descriptive explanation to be understood. The most important advantage of qualitative research is the researcher's freedom to research. It is 


\section{Macrothink}

helpful to discover the hidden, and most complex social reality as well as to understand the core meaning of the situation to keep the respondents in their natural settings. Qualitative research is conducted in natural settings and researchers often visited the site to conduct the research that enabled the researchers to develop a level of detail about the research site and participants. Another reason of adopting qualitative method is that the method of data collection of qualitative methodology involves active participation by the participants (Neuman, 2009). However, the researchers have adopted the qualitative method to make a holistic interpretation of the data. Moreover, the nature of this study is complex, interactive and sensitive enough to adopt the qualitative method.

\subsection{Data Collection Tools}

As a qualitative method, in-depth interviews was used based on semi-structured interview schedule. In-depth Interview helped the researchers to gather explorative and detailed information about the research problem. However, laborers, managers and local residents were chosen purposively for in-depth interviews.

\subsection{Sources of Data}

Both primary and secondary data were used for this study. Primary data was collected directly from the participants through direct interviews and secondary data was collected from journal articles, books, presented papers, official reports, newspapers, legal official documents, etc. to supplement primary data.

\subsection{Sampling}

To conduct this research, the researchers decided to include laborers, managers and local residents in the sampling group. The sample size of this research was 20 that was selected purposively for the sake of accurate and in-depth understanding of the problem. The researchers selected respondents purposively from different industries and surrounding areas.

\subsection{Study Area}

The area of this study is Kamrangirchar Thana in Dhaka. Kamrangirchar Thana area $3.63 \mathrm{sq}$ $\mathrm{km}$, located in between $23^{\circ} 42^{\prime}$ and $23^{\circ} 43^{\prime}$ north latitudes and in between $90^{\circ} 21^{\prime}$ and $90^{\circ} 23^{\prime}$ east longitudes. It is bounded by Hazaribagh and Lalbagh Thanas on the north, Lalbagh and Chawkbazar model Thanas on the east, Keraniganj Upazila on the south and west (Molla, 2014). 


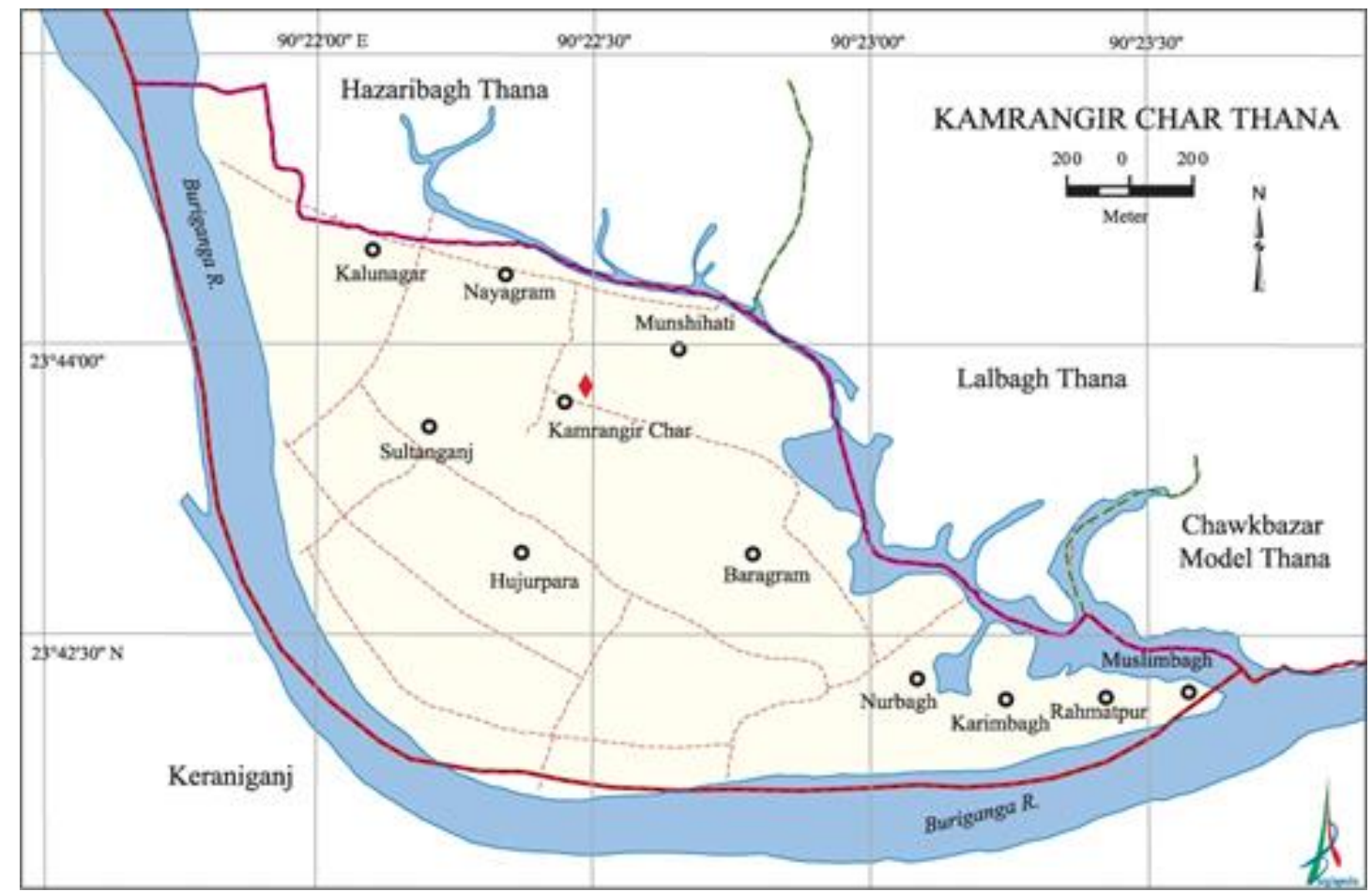

Figure 2. Map of study area (Banglapedia, 2014)

\section{Data Analysis}

\subsection{Nature of Waste Generation}

The extent of waste produced in urban areas is relational to the population and the average income of the population. Besides this, other factors such as climate, education level, the social and public approach also may affect the volume and composition of wastes. As the growth rate of the population of Dhaka city has been in elevation during the last few years, the amount of waste generation in Dhaka is growing (Yasmin \& Rahman, 2017).

The nature of waste is significant in calculating apparatus needs, classifications, and management plans, especially with respect to the implementation of disposal and resource and energy regaining possibilities. The nature of waste is also important to determine its possible environmental impacts (Hai \& Ali, 2005).

The industries from which primary data has been collected reveal that different types of wastes are being produced every day for manufacturing various kinds of products. These wastes include polythene, and plastic materials by plastics industries, coal by the battery industry, contaminated water by the Alcatra industry, toxic liquids and substances from aluminum industries and black smoke emission, etc. The amount of wastes produced per month varies depending on the size of the industries. The small-size industries produce 0.6 tons of waste per month, the medium size industries produce 1.2 tons of wastes per month, and the large-size industries produce 2.4 tons of wastes per month. 


\section{Macrothink}

Some oil and gas waste contains toxic substances that would meet the requirements of being hazardous, and which pose a risk to health and the environment, such as benzene, lead, arsenic, barium, and uranium (Earthworks, 2020).

\subsection{Categorization of Wastes}

After detecting the wastes, the hazardous waste may be categorized on the basis of threat they are likely to put on the environment.

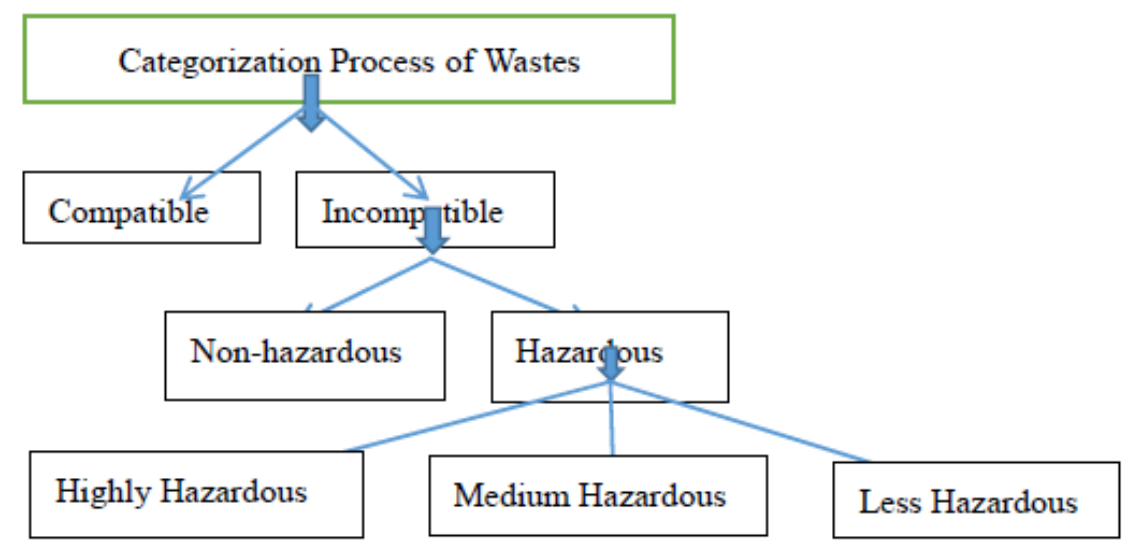

Figure 3. Categorization Process of Wastes

Source: (Misra \& Pandey, 2006)

In the study area, none of the sampled industries categorizes the wastes their industries are producing. Categorization of the produced waste can make a clear picture of the characteristics and possible effects of those wastes and may increase the level of consciousness and responsibilities of all those who are involved. But not considering all these things, all types of wastes are dumped without any categorization and treatment either into the river Buriganga or on open spaces ignoring the possible threats it may create on the surrounding environment. They don't even care about the threats these wastes may have on the environment and surrounding residents. Industries and local residents are at a very close distance there in Kamrangirchar.

\subsection{Disposal Sites of Wastes}

The Dhaka City Cooperation estimated that, of the total of 3500 tons of solid waste per day, 1800 tons are collected and dumped by the city corporation, 900 tons go to landfilling, 400 tons go to roadside and open space, 300 tons are recycled by the Tokais (Street children who live on picking objects from waste) and 100 tons are recycled at the generation premises (Yasmin \& Rahman, 2017). As there are possibly harmful reactions of hazardous wastes on environment, wastes must be characterized based on risk profile and disposal areas should be recorded. Treatment of wastes before disposal is very crucial such as detoxification, encapsulation and other treatment techniques (Misra \& Pandey, 2006). There are no defined disposal sites of wastes in Kamrangirchar. The wastes that are produced from mills, factories, 
and industries-are disposed here and there in an unplanned way such as into the Buriganga river directly, on the roadside, on the bank of Buriganga, and any other places near the industries. Most of the wastes are disposed into the Buriganga river disproportionately and discriminately. Kamrangirchar itself has been a dustbin for the industrialists that can create serious health and environmental problems. Disposal of wastes in Kamrangirchar is producing environmental risk and threat.

Solid waste disposal under the open-air and into water bodies leads to land pollution; water pollution; and air pollution. Dhaka city is meeting severe environmental ruin and public-health risk due to improper disposal of waste into low lands, on roads and other public areas, blocked drainage system by wastes dumped indiscriminately, and by pollution of water resources near uncontrolled dumping sites (Hai \& Ali, 2005).

\subsection{Disposal Infrastructure}

Storing, treating, and disposing of so much waste involves a variety of equipment and amenities, which can create risks to the environment, well-being, and assets (Earthworks, 2020). On-site storage is the secondary disposal site that collects wastes from the primary source and transferred to the selected location for processing or recycling or treatment and finally for final disposal. Secondary disposal sites are the facilities where a large number of wastes are amassed and finally transferred to the chosen sites by large vehicles such as trucks, demountable haul container trucks, etc. In Bangladesh, City Corporation is merely in charge of providing secondary disposal sites. These sites are located in selected places based on population, space availability, accessibility, and other local factors (Talukder, Mazumder, Al-Muyeed, \& Shadullah, 2011).

The infrastructural facilities of waste disposal in Kamrangirchar are very poor. There is no selected secondary disposal site, machinery, and equipment for proper management of waste disposal. Transport or vehicle system is absent in Kamrangirchar for waste management. On-site storage is the primary source and Buriganga river, low-lying land, open spaces of any kind, roadsides, etc. are secondary disposal sites in Kamrangirchar. Some industries have drainage systems that directly fall into the Buriganga river. Some of the industries burn their waste that produces a lot of polluted smoke and then throws the rest of the burnt wastes on the bank of the Buriganga river. Landfilling is another common type of waste management in Kamrangirchar. Proper management of industrial wastes needs sustainable transportation to ensure the safety of the environment. Sustainable transport means finding ways of meeting transportation needs that are environmentally safe, socially justifiable, and economically feasible in the long time span. Environmentally sustainable transportation systems should use energy resources and other natural resources at a rate not much than renewable level; produce no more waste than can be accommodated by the disposal sources' restorative capacity; and make use of land in a way that impacts less on the integrity of ecosystems (Jolley, 2004).

\subsection{Strategies for Proper Management of Waste}

A typical strategy for the management of industrial waste generally may involve an audit of wastes produced, risk assessment to avoid health hazards and environmental risk, inspecting 


\section{Macrothink}

of chances for waste reduction, reuse, recycling and recovery and valuation of waste management options, etc. (Hand, 2009).

The strategy for proper management of waste is almost an unknown word in Kamrangirchar, Dhaka. None of the industries interviewed has taken any strategy for proper management of wastes they are producing. No initiatives have been taken by the owner of the industries to dispose of the wastes their industries are emitting. They are doing whatever they wish with the wastes as there is a lack of proper legal action regarding the management of the industrial wastes. Even no NGOs have taken any initiatives regarding this matter. Lack of consciousness, lack of community participation, lack of implication of Government acts and policies and carelessness, etc. are major causes of mismanagement of industrial wastes in Kamrangirchar, Dhaka.

Solid wastes in Dhaka city are commonly produced from residential, industrial, hospital, and commercial sources. A significant portion comes from widespread cleaning up and street sweeping. Hazardous wastes from industries and hospitals are often assorted with municipal wastes, which sequentially are poorly collected and disposed of, thereby creating public health hazards (Hai \& Ali, 2005).

\subsection{Waste Management and Environment}

Consumption and production patterns were emphasized as one of the crucial features for sustainable development in the Johannesburg Declaration on Sustainable Development, adopted at the 17th plenary meeting of the World Summit on Sustainable Development on 4 September 2002. Johannesburg Plan of Implementation noted that the highest priority should be given on waste prevention and minimization (reduce), reuse and recycle (the 3Rs), and environmentally sound disposal services, and that waste prevention and minimization should be stimulated by inspiring production of reusable consumer goods (Ministry of Environment and Forests, 2010).

There is a relation to the disposal of waste and emission of GHGs. Greenhouse gases (GHGs) emissions resulting from unmanaged waste are one of the major environmental challenges causing an increase of GHGs about $3.5 \%$ to the total global emissions and equal to 49,000 million tones $\mathrm{CO} 2$ per year from 2004 to 2005. The emissions of $\mathrm{CH} 4$ from waste management caused 4\% of the global total GHGs emissions in 2010 (Shams, Sahu, Rahman, \& Ahsan, 2017). 


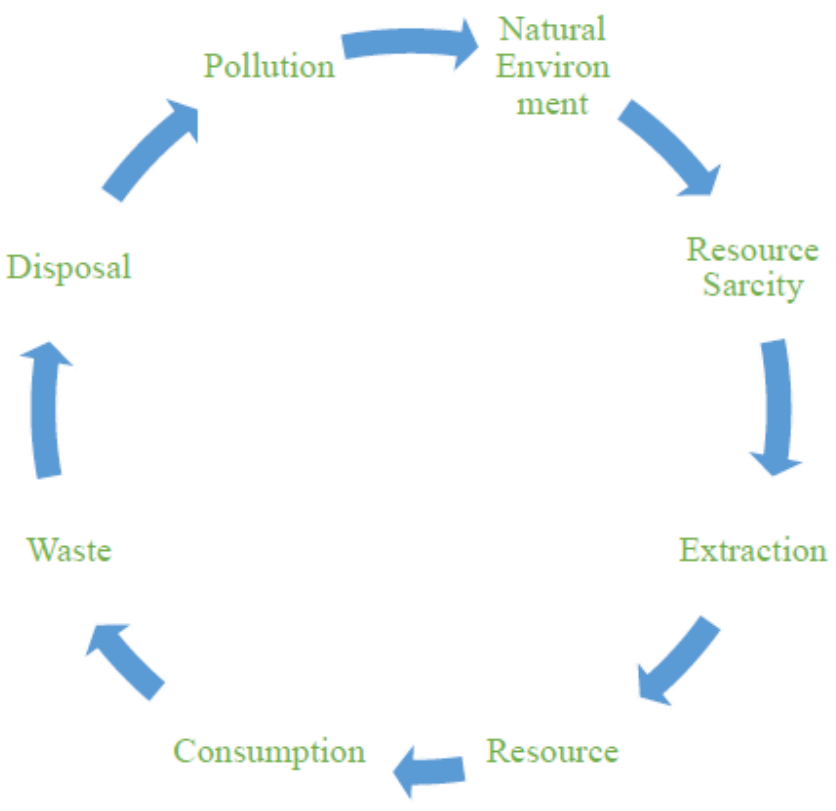

Figure 4. Unsustainable Pattern of Economy

Source: (Ministry of Environment and Forests, 2010)

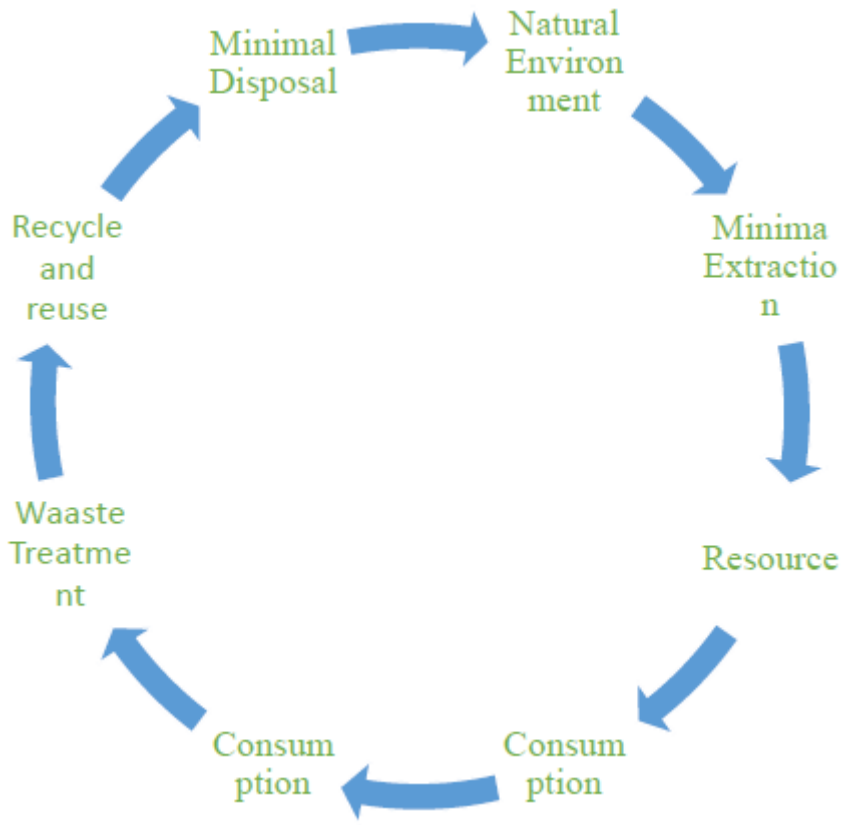

Figure 5. Sustainable Pattern of Economy

Source: (Ministry of Environment and Forests, 2010)

Two figures indicate that proper waste management is very important for a sustainable economy. Proper waste management produces less stress on the natural resources and reuse and recycling help to minimize waste generation contributing to a sustainable economy. Therefore, industrial waste management is now a matter of concern to be addressed as soon 
as possible which would encourage the stability of a sustainable economy for Bangladesh as well as reduce the pressure on the extraction of natural resources or on the eco-system.

\subsection{Practice of Government Policy}

The government, in other words, City Corporation is primarily responsible for regulating and administering waste, including planning for waste management and waste avoidance, minimization and reuse, licensing and regulation of waste transport, storage, treatment, resource recovery, and disposal, etc. (Australian Government, Department of Agriculture, Water and the Environment, 2013). But government or City Corporation needs the help of industrialists, citizens, NGOs, and the private sector to regulate the proper management of industrial wastes. The 3R Strategy has mentioned the role of government, industries, NGOs, the private sector, etc. in the implementation of the strategy (Ministry of Environment and Forests, 2010). The owner of the industries denies talking about this issue and the managers and laborers are unaware of the government policy of waste management. Again there is no authority to ensure the dissemination of knowledge on the government policy and to take care of whether the policies are adopted or not. Some of the respondents think that there is no need for any policy as they don't pollute the environment. In a word, government policy is an unknown word to the industry owners, managers, labors, and local people.

\subsection{Emission Reducing Technology}

Emission reducing technology involves many ways to reduce greenhouse gas emissions from the industrial sector, such as energy efficacy, fuel substituting, combining heat and power, using renewable energy, and the more competent use and recycling of resources. Many industrial practices have no existing low-emission technology and require carbon capture and storage to reduce emissions over the extended span (C2ES, 2019). Although it is mentioned in the government policy to adopt emission-reducing technology in the industries, not a single industry interviewed adopted any emission-reducing technology in their industries. The technologies used in the industries interviewed are inefficient and dirty and greenhouse gas-emitting technologies are absent there which is causing an increase in emission of greenhouse gas in the environment.

As stated by the Intergovernmental Panel on Climate Change (IPCC), "human influence on the climate system is clear, and anthropogenic emissions of greenhouse gases are the highest in history. The role of energy technology in reducing emissions is becoming increasingly acknowledged in the shift to a more ecological, lower-carbon energy system (Jordaan et al., 2017).

Like other developing countries, the technologies and methods of waste management practiced in the cities of Bangladesh are traditional and labor-demanding. The words "source reduction seem to be unheard of by the waste management authorities in Bangladesh. Only the informal sector is playing a significant role by doing the recycling and reusing activities while the pickers rescue recyclable wastes from dumpsites, bins, or roadsides (Ashikuzzaman \& Howlader, 2020). 


\section{Macrothink

\subsection{Reducing, Recycling, and Reusing}

Recycling and reusing of wastes are now strongly encouraged for the conservation of resources and prevention of the environment from degradation ( Hai \& Ali, 2005). Waste is an unexplored treasure. Waste could be recovered easily through The National 3R strategy and waste sources would transform into wealth. The National 3R Strategy contains waste reduction, reuse, recycling, and final disposal of the wastes into environmentally sound sites. The strategy has clearly mentioned the role of government, industries, NGOs, private sector, etc. in the implementation of the strategy (Ministry of Environment and Forests, 2010).

The plastic and pharmaceutical industries reuse incomplete and damaged products but no industries adopt recycling and reducing strategies. Only the oil industry sold their fan sheet wastes to the recycling industries Aluminum industries adopt recycling only but these industries don't have any reducing strategy or technology.

The implementation of The National 3R Strategy will ensure a comparatively sound environment and better human life. It will also prevent the indiscriminate disposal of industrial wastes into environmentally sensitive areas and reduce the negative impacts on the natural environment (Ministry of Environment and Forests, 2010).

\section{Findings and Discussion}

The findings of this research explore that different types of wastes are being produced by different industries, such as polyether, plastic powder, contaminated tars, toxic liquid, oil, soda, toxic substances, teen sheet, silver powder, etc. Most of these wastes are disposed either on the roadside or into the river Buriganga, or near the industry or on any land to fill it up. Infrastructural facilities, disposal machinery, and equipment are very poor with no defined strategies for proper management of industrial wastes. Government policies are unknown and less enacted among the industrial units in Kamrangirchar, Dhaka. There is no use of emission-reducing technology in the industries and no action has been taken against this. There is a lack of consciousness among the industrial units, community people, and lack of law enforcement agencies in Kamrangirchar. No legal compulsion is visible regarding the proper management of industrial wastes. Community participation and voice of NGOs are also absent. Reducing and recycling which are important aspects of National 3R strategies are also not adopted by any of the industries interviewed in Kamrangirchar, Dhaka. 


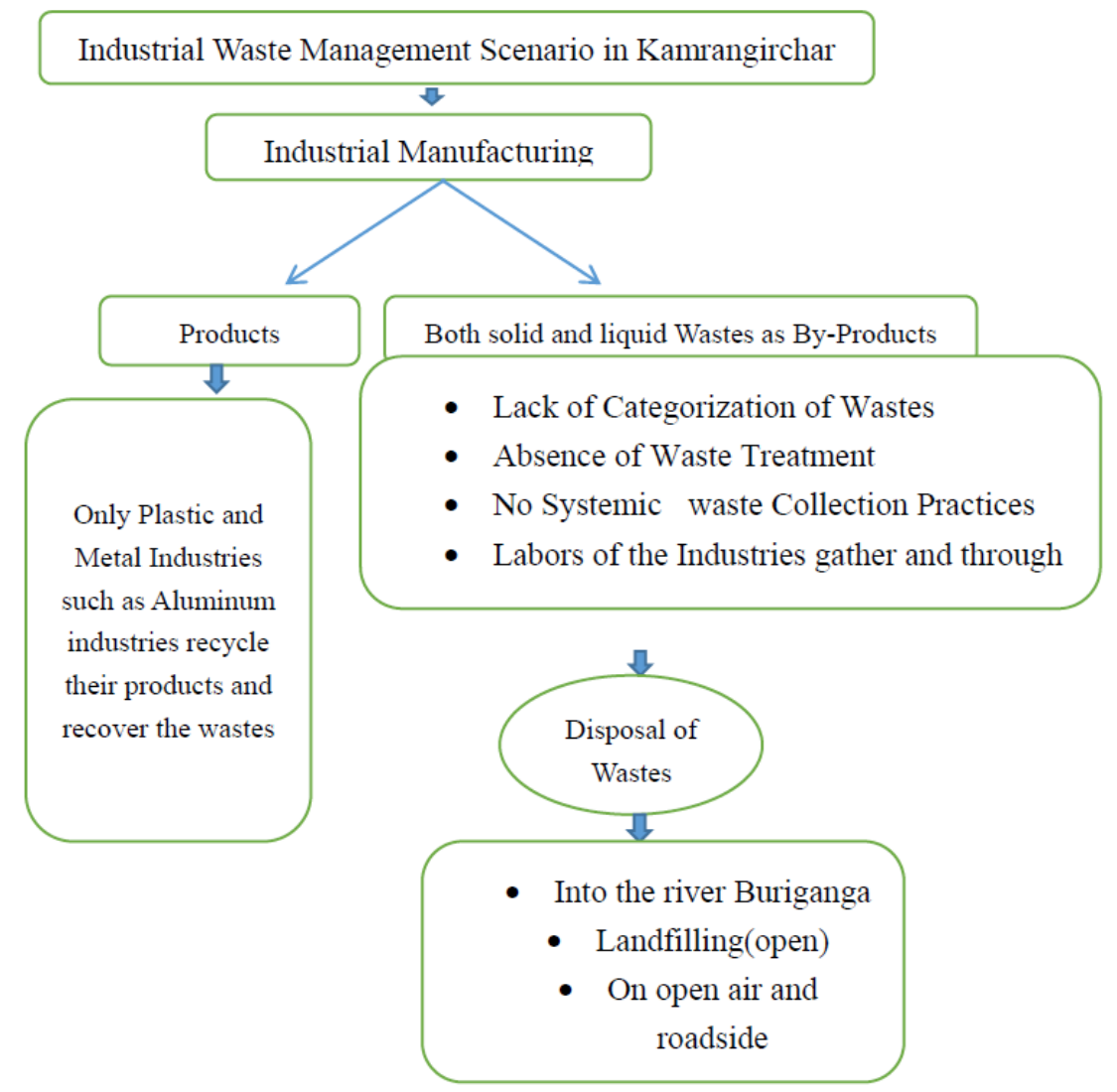

Figure 6. Industrial Waste Management Scenario in Kamrangirchar

In the aforementioned situation, the importance of the environment has been ignored inconsiderately. The Buriganga has become a river with black water with a nasty smell and mixed garbage. The water of Buriganga seems no more suitable for the fishes to live. The authors during fieldwork observed that local residual people are using the contaminated water of Buriganga for various purposes, such as bathing, washing cloths and utensils, etc. The water of Buriganga is far away from the state of drinking and other usages due to excessive pollution. Many branches of this river are dead and illegally filled with industrial wastes. There are so many drainages to the Buriganga directly from industries that contain contaminated and toxic substances and liquids. These drains are polluting the water of Buriganga which is very alarming. No industries filter the industrial liquid wastes and pour them directly into the river Buriganga.

Land pollution is also occurring in Kamrangirchar through landfilling by industrial wastes. Local Chairman's lands are being filled with industrial wastes ignoring the negative impacts on the environment (Data from Fieldwork). The wastes those are needed to be disposed of properly in right place are being used for filling land by the local government authority which is much unexpected. Wastes used for landfilling spreads bad smell and different types of infectious diseases among the residents of Kamrangirchar.

Air pollution is another negative effect of improper disposal of industrial wastes in the 


\section{Macrothink}

Kamrangirchar area. There are black smoke and bad smells of wastes almost everywhere in Kamrangirchar. People are living near the skyscraper of industrial wastes having serious health hazards.

Dumping wastes on open-air create an unhygienic environment and pose an enormous threat to the people. It also promotes the spread of diseases, pollutes water bodies, produces Carbon dioxide, and Methane which is extremely harmful to the environment (Islam, 2016).

Some plastics and Alcatra industries burn produced wastes under open-air causing air pollution by black smoke and dump the rest of this which is something like brown color either into the Buriganga river or on the bank of it. But there is no action taken by any government representatives which is creating more room for environmental pollution in Kamrangirchar.

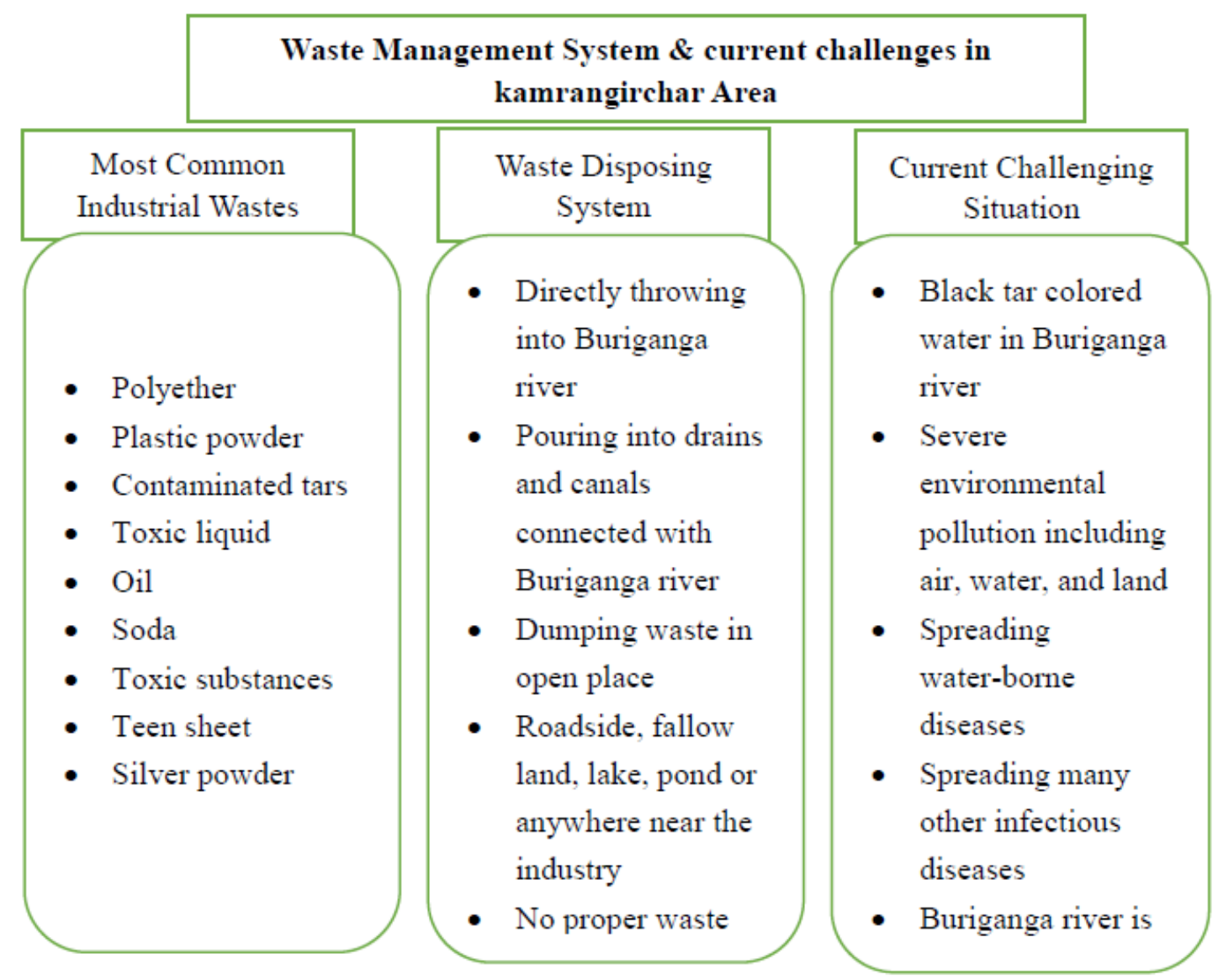

Figure 7. Waste management system and current challenging situation in Kamrangirchar area

Responsible planning, therefore, prerequisites to take into account the potential effects of the proposed development might have on its surroundings, and the potential influences that the surrounding environment might have on the proposed development. This guideline seeks to protect sensitive land and local residences from odor and dust by taking into account the potential effects of industry influencing on sensitive issues and the potential influences of 
sensitive uses affecting the industry (Victoria, 2013). Most of the industries are adjacent to local residences in Kamrangirchar creating severe health hazards for the local people. The noises from the industries are making severe sound pollution in the study area. One of the respondents said that now he is used to sleeping hearing heavy noises of industries and he cannot sleep now in a calm environment. People are being forced to reverse their natural habits because of this adverse environment to survive. There is no proper planning on what are the effects of industries on the environment and what would be the feedback from the environment in Kamrangirchar.

Some recent studies focused on the harmful impact of improper waste management practices on the environment and the significance of proper waste management, especially in developing countries. A recent study emphasized urban solid waste management including the process of collection, transportation, and disposal of waste. The study also suggested a cost-minimization approach to proper solid waste management in the urban area (Tirkolaee, Mahdavi, Esfahani, \& Weber, 2019). Some other similar studies are available in the academic world regarding the significance of proper waste management and the impact of improper waste management practices on the environment (Vani et al., 2017; Nasrin and Farjana, 2016; Shams et al., 2017; Ashikuzzaman and Howlader, 2020). The present study also explores the existing system of waste management and the impact of improper waste management on the environment of the Kamrangirchar area. From the empirical findings and the findings of some related literature the present study suggested some recommendations to improve the waste management condition of the study area.

\section{Recommendations for proper waste management in Kamrangirchar}

$>$ Increasing the level of consciousness and responsibility among the industrial units regarding the importance of environment and the negative effects of wastes on it.

$>$ Encouraging community participation.

$>$ Active administration and law enforcement units.

$>$ Enhancing the role of NGOs and private sectors.

$>$ Active government representatives.

$>$ Financial and technological support to the industrial units from government.

$>$ Developing advanced infrastructural facilities.

$>$ Providing sustainable transport system.

$>$ Developing adequate and suitable drainage systems.

$>$ Encouraging community based waste management system.

$>$ Encouraging practicing the 3Rs Policy-Reducing, recycling and reusing.

$>$ Improving the policies as time changes over long span.

$>$ Ensuring pollution and emission reducing technologies into all the industries.

$>$ Maintaining safe distance from residential areas and sensitive environment.

\section{Conclusion}

Industrialization, urbanization, and development are an ongoing process which is necessary 
for the human being. But when this development produces a threat to the environment, it should be solved as soon as possible. In urban areas, industrial waste has been a growing concern nowadays in Bangladesh. The disposal process of industrial waste in Kamrangirchar has received little attention despite its potential public health risks and environmental hazards. The generation of industrial wastes is increasing in amount and variety in Kamrangirchar and these wastes are not disposed of properly due to lack of proper initiatives to tackle this. The increasing volume of industrial wastes in Kamrangirchar is disposed of either on the roadside or into the river of Buriganga or used for landfill. The process of collection, separation, and disposal of industrial waste is not performed in the way it should be. As a result, the water of Buriganga, air, land, and sound are being polluted indiscriminately.

Proper initiatives and efforts have to be ensured for minimization and recycling of industrial waste before final disposal. On one hand, industrialization cannot be stopped in this modern age of technology, and on the other hand, we cannot ignore our valuable environment. Modern civilization requires industrialization and life requires a safe and sound environment. We cannot measure these two through an either-or relationship. The modern world requires both. Therefore, proper management of industrial waste is essential. It can be handled in a very effective way if the industrial units, government, and general people of the country become conscious and responsible. The existing policy has to be implemented and facilities should be expanded for better management of industrial waste and for a sound environment for the human being to live.

Although this paper explores some key findings regarding waste management and its impact on the environment, it is not free from limitations. The qualitative method is used to explore a deeper understanding of the problem by using purposive sampling procedure. A quantitative research can be conducted by using random sampling to find out more detailed understanding of the problem. Moreover, there is always a possibility of being biased in purposive sampling method, although, the researchers were very careful about bias. However, after considering the findings of this paper and some other related works, the researchers and the policymakers should come forward to address the problem and to find out the possible solution of this problem.

\section{References}

Banglapedia. (2013). Australian Government, Department of Agriculture, Water and the Environment. [Online] Available:

https://www.environment.gov.au/protection/waste-resource-recovery/national-waste-reports/n ational-waste-report-2013/policies-and-governance

Ashikuzzaman, M., \& Howlader, M. H. (2020). Sustainable Solid Waste Management in Bangladesh: Issues and Challenges. In A. Pariatamby, F. S. Hamid, \& M. S. Bhatti (Eds.), Sustainable Waste Management Challenges in Developing Countries (pp. 35-55). IGI Global. https://doi.org/10.4018/978-1-7998-0198-6.ch002

C2ES. (2019). Controlling Industrial Greenhouse Gas Emissions. Retrieved October 10, 2020, from C2ES: https://www.c2es.org/content/regulating-industrial-sector-carbon-emissions/ 


\section{Macrothink}

Environmental Management and Sustainable Development

ISSN 2164-7682

2021, Vol. 10, No. 1

Green, D. D. (2010). Managing Hazardous Wastes. Hong Kong, China: Asian Development Bank. [Online] Available:

https://www.adb.org/sites/default/files/project-document/62157/38401-01-reg-tacr-02.pdf

Hai, F. 1., \& Ali, M. (2005). A Study on Solid Waste Management System of Dhaka City Corporation: Effect of Composting and Landfill Location. UAP Journal of Civil and Environmental Engineering, 1(1), 18-26.

Hand, C. L. (2009). WASTE MANAGEMENT AND MINIMIZATION. In S. R. Smith, C. Cheeseman, \& N. Blakey (Eds.), Waste Management in Industry (Vol. 1). Eolss Publishers Co. UK.

Islam, F. (2016). Solid Waste Management System in Dhaka City of Bangladesh. Journal of Moder Science and Technology, 4(1), 192-209.

Jolley, A. (2004). New Technologies, Industry Developments and Emission. Centre for Strategic Economic Studies. https://doi.org/10.1016/S1365-6937(04)00143-1

Jordaan, S. M., Romo-Rabago, E., McLeary, R., Reidy, L., Nazari, J., \& Herremans, M. I. (2017). The role of energy technology innovation in reducing greenhouse gas emissions: A case study of Canada. Renewable and Sustainable Energy Reviews, 78, 1397-1409.

https://doi.org/10.1016/j.rser.2017.05.162

Mapcarta (Nd.). (2020). [Online] Available: https://mapcarta.com/N3478504005

Matter, A., Dietschi, M., \& Zurbrügg, C. (2013). Improving the informal recycling sector through segregation of waste in the household-The Case of Dhaka Bangladesh. Habitat International, 38, 150-156. https://doi.org/10.1016/j.habitatint.2012.06.001

Ministry of Environment and Forests, B. (2010). National 3R Strategy for Waste Management. Dhaka. [Online] Available:

http://wasteconcern.org/wp-content/uploads/2016/04/National_3r_Strategy.pdf

Misra, V., \& Pandey, S. (2006). Hazardous waste, impact on health and environment for development of better waste management strategies in future in India. Environment International, 31(3), 417-431. https://doi.org/10.1016/j.envint.2004.08.005

MOEF. (2013). Bangladesh initiatives towards 3R approaches: A Country Analysis Paper. Ha Noi, Vietnam. [Online] Available:

https://www.uncrd.or.jp/content/documents/Country\%20Analysis\%20Paper_Bangladesh.pdf

Nasrin, F. (2016). Waste Management in Bangladesh: Current Situation and Suggestions for Action. International Research Journal of Social Sciences, 5(10), 36-42.

Neuman, W. L. (2009). Social Research Methods: Qualitative and Quantitative Approaches (7th ed.). New York: Pearson.

Shams, S., Sahu, J. N., Rahman, S. S., \& Ahsan, A. (2017). Sustainable waste management policy in Bangladesh for reduction of greenhouse gases. Sustainable Cities and Society, 33, 18-26. https://doi.org/10.1016/j.scs.2017.05.008 
Talukder, A., Mazumder, S., Al-Muyeed, A., \& Shadullah, A. (2011). Solid Waste Management Practice in Dhaka City. Khulna. p. 1-10.

Tania, F. (2014). Solid Waste Management of Dhaka City: A Socio-economic analysis. Banglavision, 13(1), 91-100.

Tirkolaee, E. B., Mahdavi, I., Esfahani, M. M., \& Weber, G.-W. (2019). A hybrid augmented ant colony optimization for the multi-trip capacitated arc routing problem under fuzzy demands for urban solid waste management. Waste Management \& Research, 38(2), 156-172. https://doi.org/10.1177/0734242X19865782

Vani, S. S., Bhaumik, S., Nandan, A., \& Siddiqui , N. 1. (2017, March). Hazardous Waste Impact on health and Environment for sustainable development in India. World Scientific News, 70(2), 158-172.

Neuman, W. L. (1997). Social Research Methods: Qualitative and Quantitative Approaches. London: Allyn and Bacon.

Yasmin, S., \& Rahman, M. (2017). A Review of Solid Waste Management Practice in Dhaka City, Bangladesh. International Journal of Environmental Protection and Policy, 5(2), 19-25. https://doi.org/10.11648/j.ijepp.20170502.11

Banglapedia. (2014, June 30). [Online] Available:

http://en.banglapedia.org/index.php?title=File:KamrangircharThana.jpg

Molla, M. T. (2014, August 10). Kamrangirchar Thana. Banglapedia:National Encyclopedia of Bangladesh.

Amin, A. N. (2017, November). Bangladesh, Country Chapter, State of the 3Rs in Asia and the Pacific. Kamiyamaguchi, Hayama, Kanagawa, 240-0115, Japan: Institute for Global Environmental Strategies (IGES).

Earthworks. (2020, October 8). [Online] Available:

https://www.earthworks.org/issues/waste_management_infrastructure/

\section{Copyright Disclaimer}

Copyright for this article is retained by the author(s), with first publication rights granted to the journal.

This is an open-access article distributed under the terms and conditions of the Creative Commons Attribution license (http://creativecommons.org/licenses/by/4.0/). 